\title{
Lymphadenitis and Fever: First Presentation of Kawasaki Disease
}

\author{
Lenfadenit ve Ateș: Kawasaki Hastalığının Illk Bulgusu
}

\author{
Şule Gökçe1, Pelin Elibol1, Güldane Koturoğlu1, Yasemin Özdemir Şahan2, Zülal Ülger Tutar2 \\ ${ }^{1}$ Ege University Faculty of Medicine, Department of Pediatrics, Izmir, Turkey \\ 2Ege University Faculty of Medicine, Department of Pediatrics, Division of Pediatric Cardiology, Izmir, Turkey
}

\begin{abstract}
Kawasaki disease is a vasculitis of infant and childhood period. Diagnosis of Kawasaki disease is based on clinical criteria including cervical lymphadenopathy. Here we reported a 3.5-year-old boy presenting with Kawasaki disease mimicking bacterial lymphadenitis and fever. If a child presents with lymphadenopathy only which is unresponsive to antibiotics, Kawasaki disease should be considered.

Keywords: Kawasaki disease, bacterial lymphadenitis, child
\end{abstract}

$\ddot{0 Z Z}$

Kawasaki hastalı̆ı̆ çocukluk ve infant dönemin bir vaskülitidir. Servikal lenfadenopatinin de içinde yer aldığı bazı klinik kriterler ile tanı konulur. Bu yazıda kliniğimize ateş ve bakteriyel lenfadenit kliniği ile başvuran 3,5 yaşında bir erkek olgu sunulmuştur. Antibiyotiğe cevapsız bakteriyel lenfadenit kliniği ile başvuran olgularda Kawasaki hastalığı göz önünde bulundurulmalıdır. Anahtar Kelimeler: Kawasaki hastalı̆̆ı, bakteriyel lenfadenit, çocuk

and cervical adenopathy and may be misdiagnosed as bacterial cervical lymphadenitis. Therefore, specific treatment is delayed, leading to serious cardiac sequelae.

Herein, we report an unusual case of KD: a 3.5-yearold boy who presented with fever and bilateral cervical lymphadenitis as initial manifestations.

\section{Case Report}

A 3.5-year-old boy presented with a high fever, swelling in the neck, fatigue, restlessness and dehydration. He had a history of persistent fever for ten days, reaching $40.5^{\circ} \mathrm{C}$, especially at nights. Before admission, he received an oral treatment of amoxicillin-clavulanate $90 \mathrm{mg} / \mathrm{kg} / 24 \mathrm{hr}$ for 4 days ceftriaxone $80 \mathrm{mg} / \mathrm{kg} / 24 \mathrm{hr}$, and two doses of metronidazole $30 \mathrm{mg} / \mathrm{kg} / 24 \mathrm{hr}$ parenterally. Physical examination revealed

\section{Address for Correspondence/Yazıșma Adresi}

Şule Gökçe MD, Ege University Faculty of Medicine, Department of Pediatrics, Izmir, Turkey

Phone: +90 2323901244 E-mail: sule.gokce@yahoo.com

Received/Geliş tarihi: 23.11.2015 Accepted/Kabul tarihi: 08.03.2016

${ }^{\circ}$ Copyright 2017 by Ege University and Ege Children's Foundation

The Journal of Pediatric Research, published by Galenos Yayınevi. 
three lymph node enlargements unilaterally in cervical region, the largest being, $30 \mathrm{~mm} \times 30 \mathrm{~mm}$ in diameter; fixed, solitary, tender without fluctuation. Non-specific complaints were present including abdominal cramping, weight loss due to decreased oral intake and change in defecation. Blood testing showed white blood cell (WBC): 14.5000/mm with neutrophil predominance (55\%); hemoglobin: $10.4 \mathrm{~g} /$ dL; platelet counts: $291.000 / \mathrm{mm}^{3}$, C-reactive protein (CRP): $7.5 \mathrm{mg} / \mathrm{dL}$, and sedimentation ratio: $66 \mathrm{~mm} / \mathrm{h}$. Biochemical markers were normal except for slightly reduced albumin $(2.9 \mathrm{~g} / \mathrm{dL})$. Soft-tissue neck ultrasonography revealed multiple lymph nodes, of fusiform shaped-reactive nature, of which the biggest was located at the right juguler triangle, $30 \times 12$ $\mathrm{mm}$ in diameter. Neck computerized tomography was obtained to exclude deep cervical infection. Multiple and diffuse lymphadenitis were seen at the level of superficial and deep cervical lymph nodes. The biggest one was on the right side, at jugulodigastric localization, 32×16×20 mm in diameter (Figure 1). Treatment with intravenous clindamycin $30 \mathrm{mg} / \mathrm{kg} / 24 \mathrm{hr}$ was initiated to treat possible infectious components, hydration was administered via inravenous route, but his condition did not improve, and the neck masses remained painful. The patient exhibited with enlarged cervical nodes three days after admission. The throat swab culture and blood culture samples taken at the time of admission were negative for infection. Incomplete Kawasaki syndrome was suspected due to the child's irritated, tired appearance; continuing fever, and bilateral cervical lymphadenitis an echocardiography was performed showing increased thickness of coronary artery walls (Figure 2). The patient was diagnosed with KD based on the echocardiographic findings. Immediate treatment with intravenous immnunoglobulin (2 $\mathrm{g} / \mathrm{kg}$ for one day) and $80 \mathrm{mg} / \mathrm{kg} /$ day asetilesalysalic acid was initiated. Significant improvement was observed on the first day after the treatment. The lymph node sizes and acute phase response were reduced on the following day. Besides, the patient's fever subsided and the other symptoms resolved. Control laboratory analyses revealed: WBC counts $9650 / \mathrm{mm}^{3}$, platelet counts $691.000 / \mathrm{mm}^{3}$, sedimentation ratio $30 \mathrm{~mm} / \mathrm{h}$, and CRP $0.3 \mathrm{mg} / \mathrm{dL}$. Follow-up echocardiography examinations after one week were normal. On the 9th day of the treatment, desquamation on the patient's fingers and toes, and macular rash on his feet were observed. Two weeks later, asetilsalysalic acid treatment dose was decreased to antiaggregant level, and the patient was discharged. Followup echocardiography examinations during the 2-month period after discharge were normal.

\section{Discussion}

$\mathrm{KD}$ is a systemic vasculitis affecting small and mediumsized vessels and is most often seen in children between 6 months and 5 years (4). It's etiology is still unknown but clinical, laboratory and epidemiological features suggest an infectious origin (5). Typical Kawasaki symptoms include fever- of more than 5 days-being unresponsive to antibiotic treatment, cervical lymphadenitis, nonpurulent bilateral conjuctival injection, oral mucosal changes, hand-foot changes in the body. In KD, lymph node enlargements are less frequent than the other findings (25-50\%) (6), and their incidence is more frequent in patients of older ages. Lymphadenopathy and fever have previously been reported as initial presentations of KD in the literature. Additionaly KD has sometimes mimicked bacterial lymphadenitis by including prominent swelling, pain, and redness with high body temperatures. This may cause a delay in the diagnosis of KD and increase the risk of coronary artery involvement. Nomura et al. (7) evaluated laboratory and clinical findings of 187 patients with confirmed KD and 16 patients presented with only fever and cervical lymphadenopathy on admission. Three of sixteen patients presented with bacterial cervical lymphadenitis or deep neck infection (7). Kubota et al. (8) reported that patients with KD presenting with only fever and cervical lymphadenopathy were older and admitted earlier. Another case report by April et al. (9) demonstrated that patients with lymphadenopathy were older and had stronger inflammatory responses than those without lymphadenopathy. Yap et al. (10) reported a

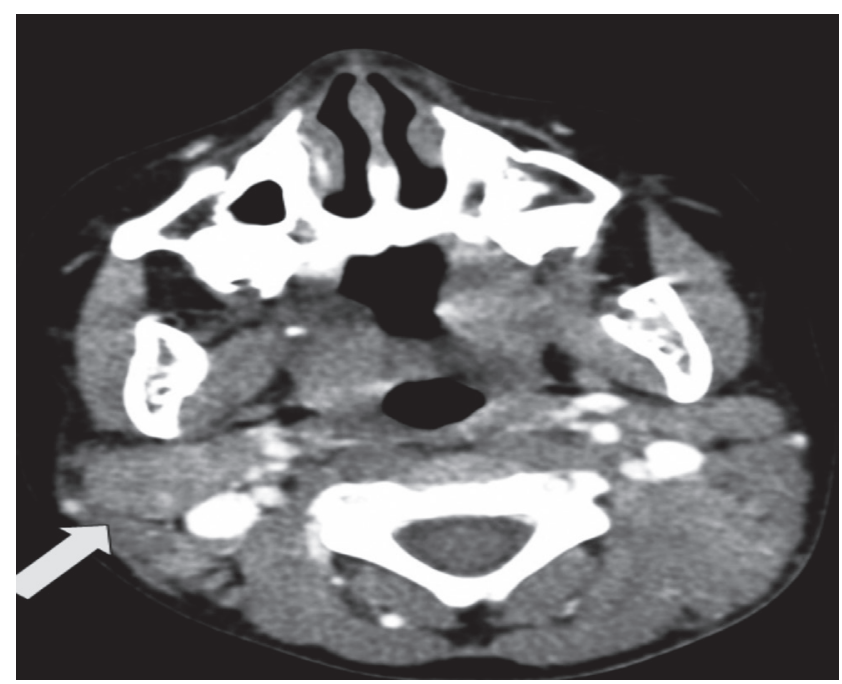

Figure 1. Computerized tomography scan of neck, both deep and superficial lymph node on the right, the largest chain of $32 \times 16 \times 20$ $\mathrm{mm}$, including common and multiple lymphadenomegalies

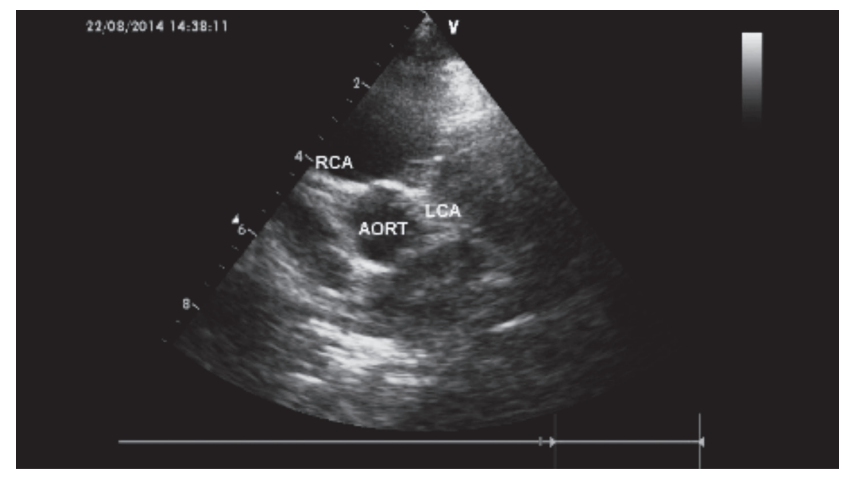

Figure 2. Echocardiography showing increased thickness of coronary artery walls especially right coronary artery

RCA: Right coronary artery, LCA: Left coronary artery 
10 year-old boy, admitted with acute exudative tonsillitis and bilateral cervical lymphadenitis. The patient had a 4-day history of fever, sore throat, neck pain and an unresponsive fever despite 72 hours of intravenous antibiotic treatment. Fourteen days post admission the patient presented sheetlike desquamation of the hands, feet, and perianal region. KD was diagnosed mimicking bacterial lymphadenitis and fever. They suggested that children presenting with sole fever and cervical lymphadenopathy could be considered as having KD.

In our case we tried to emphasize that KD can present as bacterial lymphadenitis. In case of acute bacterial lymphadenitis unresponsive to antibiotic regimen, KD should be considered in differential diagnosis.

\section{Ethics}

Informed Consent: Consent form was filled out by all participants.

Peer-review: Internally peer-reviewed.

\section{Authorship Contributions}

Surgical and Medical Practices: Şule Gökçe, Pelin Elibol, Güldane Koturoğlu, Concept: Güldane Koturoğlu, Zülal Ülger Tutar, Design: Şule Gökçe, Yasemin Özdemir Şahan, Data Collection or Processing: Şule Gökçe, Pelin Elibol, Analysis or Interpretation: Şule Gökçe, Literature Search: Şule Gökçe, Pelin Elibol, Güldane Koturoğlu, Yasemin Özdemir Şahan, Zülal Ülger Tutar, Writing: Şule Gökçe, Pelin Elibol, Güldane Koturoğlu.

Conflict of Interest: No conflict of interest was declared by the authors.

Financial Disclosure: The authors declared that this study received no financial support.

\section{References}

1. Son MB, Newburger JW. Kawasaki disease. In: Kliegman RM, Stanton BF, Geme JWSt III, Schor NF, Behrman RE, eds.
Nelson Textbook of Pediatrics, 19th edition. Philadelphia, $\mathrm{Pa}$, USA: Elsevier; 2011. pp. 862-5.

2. Takahashi K, Oharaseki T, Yokouchi Y. Pathogenesis of Kawasaki Disease. Clin Exp Immunol 2011;164:20-2.

3. Burns JC, Mason WH, Glode MP, et al. Clinical and epidemiologic characteristics of patients referred for evaluation of possible Kawasaki disease. United States Multicenter Kawasaki Disease Study Group. J Pediatr 1991;118:680-6.

4. Anderson BL, Guiot AB, Timm NL. An atypical presentation of atypical Kawasaki disease. Pediatr Emerg Care 2014;30:491 2.

5. Suddleson EA, Reid B, Woolley MM, Takahashi M. Hydrops of the gallbladder associated with Kawasaki syndrome. J Pediatr Surg 1987;22:956-9.

6. Tashiro N, Matsubara T, Uchida M, Katayama K, Ichiyama T, Furukawa S. Ultrasonographic evaluation of cervical lymph nodes in Kawasaki disease. Pediatrics 2002;109:E77-7.

7. Nomura Y, Arata M, Koriyama C, et al. A Severe Form of Kawasaki Disease Presenting with Only Fever and Cervical Lymphadenopathy at Admission. J Pediatr 2010;156:78691.

8. Kubota M, Usami I, Yamakawa M, Tomita Y, Haruta T. Kawasaki disease with lymphadenopathy and fever as sole initial manifestations. J Paediatr Child Health 2008;44:35962.

9. April MM, Burns JC, Newburger JW, Healy GB. Kawasaki disease and cervical adenopathy. Arch Otolaryngol Head Neck Surg 1989;115:512-4.

10. Yap CY, Lin LH, Wang NK. An atypical presentation of Kawasaki disease: a 10-year-old boy with acute exudative tonsillitis and bilateral cervical lymphadenitis. Clinics (Sao Paulo) 2012;67:689-92. 